\title{
The nutritional herb Epimedium grandiflorum inhibits the growth in a model for the Luminal A molecular subtype of breast cancer
}

\author{
NITIN T. TELANG ${ }^{1}$, GOU LI $^{2}$, MEENA KATDARE ${ }^{3,4}$, DANIEL W. SEPKOVIC ${ }^{5}$, \\ H. LEON BRADLOW ${ }^{5}$ and GEORGE Y.C. WONG ${ }^{2,6}$
}

\author{
${ }^{1}$ Cancer Prevention Research Program, Palindrome Liaisons Consultants, Montvale, NJ 07645-1559; \\ ${ }^{2}$ American Foundation for Chinese Medicine, Inc., Long Island, NY 11103-0905; ${ }^{3}$ Skin of Color Research Institute, \\ Hampton University, Hampton, VA 23668; ${ }^{4}$ Department of Dermatology and Leroy T. Canoles Jr. Cancer Research \\ Center, Eastern Virginia Medical School, Norfolk, VA 23507; ${ }^{5}$ Hackensack University Medical Center, \\ Hackensack, NJ 07601; ${ }^{6}$ Breast Center, Maimonides Medical Center, Brooklyn, NY 11219, USA
}

Received September 5, 2016; Accepted December 16, 2016

DOI: $10.3892 / 01.2017 .5720$

\begin{abstract}
The Luminal A subtype of breast cancer expresses the estrogen receptor (ER)- $\alpha$ and progesterone receptor (PR), but not the human epidermal growth factor receptor (HER)-2 oncogene. This subtype of breast cancer responds to endocrine therapy involving the use of selective estrogen receptor modulators and/or inhibitors of estrogen biosynthesis. However, these therapeutic agents are frequently associated with long-term systemic toxicity and acquired tumor resistance, emphasizing the need to identify non-toxic alternative treatments for chemo-endocrine therapy responsive breast cancer. The present study utilized the human mammary carcinoma-derived, $\mathrm{ER}^{+} / \mathrm{PR}^{+} / \mathrm{HER}-2^{-} \mathrm{MCF}-7$ cell line as a model of the Luminal A subtype of breast cancer to examine the growth inhibitory effect of the Chinese nutritional herb Epimedium grandiflorum (EG) and determine the mechanisms underlying this effect. MCF-7 cells maintained in a serum-depleted culture medium retained their ability to grow in response to $17 \beta$-estradiol $\left(\mathrm{E}_{2}\right)$. Treatment of the MCF-7 cells with $E G$ resulted in dose-dependent inhibition of $E_{2}$-promoted growth. Mechanistically, EG inhibited $\mathrm{E}_{2}$-promoted cell cycle progression through $\mathrm{G}_{1}$ stage arrest and modulated the cellular metabolism of $\mathrm{E}_{2}$, increasing the formation of the anti-proliferative metabolites 2-hydroxyestrone and estriol. Long-term treatment of MCF-7 cells with EG inhibited $\mathrm{E}_{2}$-promoted anchorage independent growth, a surrogate in vitro biomarker of tumorigenesis. In conclusion, the results of the present study demonstrate the growth inhibitory effects of EG on MCF-7 cells and identified clinically relevant mechanistic leads for its anti-tumorigenic efficacy.
\end{abstract}

Correspondence to: Dr Nitin T. Telang, Cancer Prevention Research Program, Palindrome Liaisons Consultants, Suite B, 10 Rolling Ridge Road, Montvale, NJ 07645-1559, USA

E-mail: entitytoo@gmail.com; ntelang3@gmail.com

Key words: nutritional herb, prevention, breast cancer

\section{Introduction}

Metastatic breast cancer is one of the leading causes of breast-cancer associated mortality in the United States, and the American Cancer Society (Atlanta, GA, USA) projections for breast cancer incidence and mortality rates estimate 246,660 newly diagnosed cases of invasive breast cancer and 40,450 metastatic breast cancer-associated mortalities in women in 2017 (1). These figures emphasize the requirement for a more precise molecular classification of breast cancer for subtype-specific targeted therapy, in addition to the necessity to identify novel, non-toxic and efficacious modalities as alternatives for cancer prevention and therapy.

The global gene expression profiling of breast cancer has led to the identification of molecularly distinct subtypes. Patients with the molecular subtype Luminal A express estrogen receptor- $\alpha$ (ER)- $\alpha$ and progesterone receptor (PR), and they lack the expression of human epidermal growth factor receptor-2 (HER-2). Patients with this subtype respond to endocrine-based targeted therapy, such as selective ER modulators and specific small molecule inhibitors of estrogen biosynthesis (2-4). However, long-term endocrine-based therapy has been associated with adverse systemic toxicity, acquired tumor resistance and the emergence of drug resistant cancer stem cells that compromise therapeutic efficacy and promote disease progression (4-6).

Complementary and alternative medicine using herbal products has been applied to endocrine therapy-responsive patients with breast cancer, as a potential method of reducing therapy-associated toxicity. Several nutritional herbs, including Lycium barbarum (LB), Cornus offcinalis (CO) and Epimedium grandiflorum (EG), are essential components of herbal formulations that are used in traditional Chinese medicine as palliative and/or adjuvant treatment options for women with breast cancer $(7,8)$. The majority of nutritional herbs display potent immunomodulatory and antiangiogenic properties in vivo (7). However, the underlying molecular signaling pathways and targets that are responsible for the growth inhibitory effects of these herbs on breast cancer cells remain to be systematically elucidated. 
The human mammary carcinoma-derived cell line MCF-7 expresses ER- $\alpha$ and PR, and lacks HER-2 expression, thus representing an accepted pre-clinical cell model for the Luminal A molecular subtype of breast cancer (2-4). Previous studies using MCF-7 cells as a model for the Luminal A breast cancer subtype have demonstrated the direct growth inhibitory efficacy of extracts from Chinese nutritional herbs, such as LB and CO, that function through distinct mechanistic pathways $(9,10)$. The present study utilized MCF-7 cells to investigate the direct growth inhibitory effects of the Chinese nutritional herb EG and identify the potential molecular mechanisms underlying its efficacy.

\section{Materials and methods}

Cell culture. The ER- $\alpha^{+} / \mathrm{PR}^{+} / \mathrm{HER}-2^{-}$human mammary carcinoma-derived cell line $\mathrm{MCF}-7$ was obtained from the Michigan Cancer Foundation (Detroit, MI, USA). The cells were cultured in Dulbecco's modified Eagle's medium: Nutrient Mixture F-12 (DMEM/F-12) supplemented with heat inactivated $7 \%$ fetal calf serum, 2 mM L-glutamine, $1 \%$ penicillin-streptomycin mixture (all Gibco; Thermo Fisher Scientific, Inc., Waltham, MA, USA), $10 \mu \mathrm{g} / \mathrm{ml}$ insulin (Ely Lilly and Company, Indianapolis, IN, USA) and $1 \mu \mathrm{M}$ dexamethasone (Sigma-Aldrich; Merck Millipore, Darmstadt, Germany), following published protocols (9-11).

In the present study, MCF-7 cells were adapted for long-term growth in serum-depleted medium through maintaining the cells in DMEM/F-12 supplemented with $0.7 \%$ fetal calf serum $\left[17 \beta\right.$-estradiol $\left.\left(\mathrm{E}_{2}\right)<1 \mathrm{nM}\right]$ for $\geq 5$ passages. Stock cultures were routinely maintained in DMEM/F-12 supplemented with $0.7 \%$ fetal calf serum in a humidified atmosphere with $5 \% \mathrm{CO}_{2}$ at $37^{\circ} \mathrm{C}$. Cells were sub-cultured in a 1:4 ratio once they reached $80 \%$ confluency.

Growth parameters. Cell population doubling time was determined during the exponential growth phase. Viable cell counts were performed 24, 48, 72 and $96 \mathrm{~h}$ post-seeding of $1 \times 10^{5}$ cells using a trypan blue exclusion cell viability assay kit (Sigma-Aldrich; Merck Millipore), following the protocol supplied by the vendor. The data are expressed as the mean of the four time points. Similarly, saturation density was determined by the viable cell count on day 7 post-seeding, using the trypan blue cell viability assay kit. The experiment for anchorage independent (AI) growth was performed using 12-wells/treatment group. AI growth was evaluated by determining the number of AI colonies that had developed in $0.33 \%$ Bacto-agar (Sigma-Aldrich; Merck Millipore) on day 21 post-seeding of $1 \times 10^{3}$ cells, following published optimized protocols (9-11).

Aqueous extract of EG. To prepare an aqueous extract, $20 \mathrm{~g}$ of leaves and stems from EG were boiled in $200 \mathrm{ml}$ of deionized water until the volume had reduced to $100 \mathrm{ml}$, and the supernatant was subsequently collected (extract 1). The resultant residue was further boiled in $100 \mathrm{ml}$ of water until the volume had reduced to $50 \mathrm{ml}$ (extract 2). The two extracts (100 and $50 \mathrm{ml}$ ) were combined and further concentrated through boiling until the volume had reduced to $25 \mathrm{ml}$. These combined extracts were centrifuged at $500 \mathrm{x} g$ at room temperature for $10 \mathrm{~min}$. The resulting supernatant $(20 \mathrm{ml})$ was collected and stored in $5 \mathrm{ml}$ aliquots at $-20^{\circ} \mathrm{C}$. The stock solution $(100 \%)$ was serially diluted in DMEM/F-12 to obtain working solutions of 2.0, 1.0 and $0.5 \%$ for subsequent experiments.

Dose-response analysis. To determine the growth inhibitory effects, and the minimum effective and maximum cytostatic concentrations of EG, the MCF-7 cells were treated with increasing concentrations of EG $(0.5,1.0$ and $2.0 \%)$. The experiments for the dose-response of EG were performed using 6 flasks/treatment group. Viable cell counts were determined on day 7 post-seeding of $1.0 \times 10^{5}$ cells using the trypan blue exclusion cell viability assay as described above. Dose-response analysis identified the half maximal inhibitory concentration $\left(\mathrm{IC}_{50}\right)$, the maximum cytostatic concentration $\left(\mathrm{IC}_{90}\right)$ and the toxic concentration of EG for growth inhibition. The $\mathrm{IC}_{90}$ was defined as the highest dose of EG that resulted in a viable cell count $\geq$ the initial seeding density. The toxic concentration was defined as the lowest dose of EG that resulted in a viable cell count $<$ the initial seeding density.

Cell cycle progression. To examine the effect of EG on cell cycle progression, MCF-7 cell cultures treated for $48 \mathrm{~h}$ with $20 \mathrm{nM} \mathrm{E}_{2}$ (Sigma-Aldrich; Merck Millipore) alone (control) or with $20 \mathrm{nM} \mathrm{E}_{2}+1.0 \% \mathrm{EG}$ were analyzed using fluorescence-activated cell sorting, following an optimized protocol $(12,13)$. Briefly, trypsinized cell cultures from the control and treatment groups were stained with propidium iodide (Calbiochem; Merck Millipore), and the percentage of the cell population in $G_{1}, S$ and $G_{2} / M$ phases of the cell cycle was monitored using the EPICS ${ }^{\circledR} 752$ flow cytometer (Beckman Coulter, Inc., Brea, CA, USA), equipped with a $488 \mathrm{nM}$ excitation filter and a $630 \mathrm{nM}$ longpass filter. Cell cycle phase distribution was analyzed using MultiCycle MPLUS 2.0 software (Phoenix Flow Systems, San Diego, CA, USA). Results are expressed as the percentage of cells in $G_{1}, S$ and $G_{2} / M$ phases of the cell cycle. In addition, the $G_{1}: S+G_{2} / M$ ratio of the number of cells in each phase is presented. This assay was performed using 3 flasks/treatment group.

Cellular metabolism of $E_{2}$. To examine the effect of EG on the cellular metabolism of $\mathrm{E}_{2}$, on day 1 post-seeding, $1 \times 10^{6}$ MCF-7 cells were treated with $20 \mathrm{nM} \mathrm{E}$ alone (control) or $\mathrm{E}_{2}+1.0 \% \mathrm{EG}$ for $48 \mathrm{~h}$. The media was subsequently collected and analyzed for the presence of select $E_{2}$ metabolites, such as estrone $\left(\mathrm{E}_{1}\right), 2$-hydroxyestrone $\left(2-\mathrm{OHE}_{1}\right), 16 \alpha$-hydroxyestrone $\left(16 \alpha-\mathrm{OHE}_{1}\right)$ and estriol $\left(\mathrm{E}_{3}\right)$, using gas chromatography-mass spectrometry. An Agilent $6908 \mathrm{~N}$ gas chromatograph equipped with an Agilent 5973 mass selection detector, Agilent 7683 injector and HPGI 701 CA MSD Chemstation (all Agilent Technologies, Inc., Santa Clara, CA, USA) was used following a previously optimized protocol $(9,10)$. Primary data are expressed as metabolite concentration (ng)/1×10 6 cells. Additionally, the primary data was analyzed and expressed as $2-\mathrm{OHE}_{1}: 16 \alpha-\mathrm{OHE}_{1}$ and $\mathrm{E}_{3}: 16 \alpha-\mathrm{OHE} \mathrm{E}_{1}$ ratios for $\mathrm{E}_{2}$ metabolites. This assay was performed using 3 flasks/treatment group.

Statistical analysis. Statistical analyses were performed using the Student's t-test and one-way analysis of variance, 
followed by a Dunnett's Multiple Range Test $(\alpha=0.05)$ where appropriate. All tests were performed using GraphPad Prism ${ }^{\circledR}$ software (version 5.0; GraphPad Software, Inc., La Jolla, CA, USA). $\mathrm{P}<0.05$ was considered to indicate a statistically significant difference. The threshold of $\alpha=0.05$ was selected for comparison of multiple treatment groups using the Dunnett's Multiple Range Test.

\section{Results}

Growth-promoting effects of $E_{2}$. Results of the investigation into the effects of $\mathrm{E}_{2}$ on MCF-7 cells adapted for growth in $0.7 \%$ serum $\left(\mathrm{E}_{2},<1 \mathrm{nM}\right)$ vs. those in $20 \mathrm{nM} \mathrm{E} \mathrm{E}_{2}$ are presented in Table I. MCF-7 cells treated with $20 \mathrm{nM} \mathrm{E}_{2}$ demonstrated a $17.6 \%$ decrease in the population doubling time, a $91.9 \%$ increase in the saturation density and a 1.2-fold increase in the number of AI colonies compared with the control group that had been grown in $0.7 \%$ serum $\left(\mathrm{E}_{2},<1 \mathrm{nM}\right)$. The statistical significance of the data was analyzed by one-way analysis of variance and Dunnett's Multiple Range Test $(\alpha=0.05)$.

Dose-response to EG. Results of the investigation into the growth inhibitory effects of EG on MCF-7 cells are presented in Fig. 1. A 7-day treatment with $20 \mathrm{nM} \mathrm{E}_{2}$ resulted in a viable cell count of $26.1 \pm 4.7 \times 10^{5}$, a 26 -fold increase compared with the initial seeding density $(\alpha=0.05)$. Furthermore, treatment with $20 \mathrm{nM} \mathrm{E}_{2}+0.5 \% \mathrm{EG}$ and $20 \mathrm{nM} \mathrm{E}+1.0 \% \mathrm{EG}$ resulted in a significant decrease in the viable cell counts compared with the $20 \mathrm{nM} \mathrm{E}_{2}$ alone-treated control group (20 nM E $\mathrm{E}_{2}+0.5 \% \mathrm{EG}$, $12.8 \pm 2.3 \times 10^{5} ; 52.6 \%$ decrease; $\left.\alpha=0.05\right)$ and $\left(20 \mathrm{nM} \mathrm{E}_{2}+1.0 \%\right.$ EG, $2.4 \pm 0.4 \times 10^{5} ; 87.0 \%$ decrease; $\left.\alpha=0.05\right)$. This dose-response analysis identified that $\mathrm{EG}$ had an $\mathrm{IC}_{50}$ of $0.49 \pm 0.18 \%$ and an $\mathrm{IC}_{90}$ of $1.03 \pm 0.17 \%$ (data not shown). An EG concentration of $2.0 \%$ was toxic to MCF-7 cells.

Effect of EG on cell cycle progression. Data from the investigation into the effect of $E_{2}$ and $E_{2}+E G$ on the cell cycle progression of MCF-7 cells are presented in Table II. The data demonstrates that treatment with $20 \mathrm{nM} \mathrm{E}_{2}$ induced an increase in the percentage of cells in the $S$ and $G_{2} / M$ phases, with a simultaneous decrease in the percentage of cells in the $\mathrm{G}_{1}$ phase, compared with the serum-treated control group. Furthermore, treatment with $20 \mathrm{nM} \mathrm{E}_{2}$ and the $\mathrm{IC}_{90}$ concentration of EG (1.0\%) induced pronounced $\mathrm{G}_{1}$ cell cycle arrest with a simultaneous decrease in the percentage of cells in the $S$ and $G_{2} / M$ phases, compared with the $E_{2}$ alone-treated control. Compared with the serum-treated control group, treatment with $\mathrm{E}_{2}$ resulted in a $54.3 \%$ decrease $(\alpha=0.05)$ in the $\mathrm{G}_{1}: \mathrm{S}+\mathrm{G}_{2} / \mathrm{M}$ ratio of cells. In addition, treatment with $\mathrm{EG}+\mathrm{E}_{2}$ resulted in a $76.2 \%$ increase in the $G_{1}: S+G_{2} / M$ ratio of cells compared with the $\mathrm{E}_{2}$ alone-treated control group $(\alpha=0.05)$. These results indicate that $\mathrm{E}_{2}$ accelerates cell cycle progression and that EG can attenuate the effect of $\mathrm{E}_{2}$.

Effect of EG on the cellular metabolism of $E_{2}$. Data from the investigation into the effect of $E G$ on $E_{2}$ metabolism are presented in Table III. The results demonstrate that the $E_{2}+E G$ group had a significantly increased formation rate of $\mathrm{E}_{1}(\mathrm{P}=0.01), 2-\mathrm{OHE}_{1}(\mathrm{P}=0.006)$ and $\mathrm{E}_{3}(\mathrm{P}=0.001)$ compared with the $\mathrm{E}_{2}$ alone-treated control group. EG
Table I. Growth promoting effects of $\mathrm{E}_{2}$ on MCF-7 cells.

\begin{tabular}{lcc}
\hline & \multicolumn{2}{c}{ Culture conditions } \\
\cline { 2 - 3 } & $\begin{array}{r}0.7 \% \text { serum } \\
\left(<1 \mathrm{nM} \mathrm{E}_{2}\right)\end{array}$ & $\begin{array}{r}0.7 \% \text { serum } \\
+20 \mathrm{nM} \mathrm{E}_{2}\end{array}$ \\
Growth parameter & $33.0 \pm 1.9$ & $27.2 \pm 1.6$ \\
\hline Population doubling $(\mathrm{h})^{\mathrm{a}}$ & $13.6 \pm 4.5$ & $26.1 \pm 4.7$ \\
Saturation density $\left(\mathrm{x} 10^{5}\right)^{\mathrm{b}}$ & $16.5 \pm 1.5$ & $37.2 \pm 2.1$ \\
AI colonies (no.) & $\mathrm{c}$ &
\end{tabular}

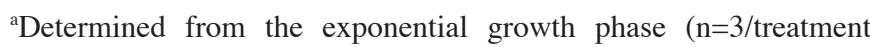
group). ${ }^{b}$ Viable cell number determined at day 7 post-seeding of $1 \times 10^{5}$ cells ( $n=3 /$ treatment group). ${ }^{c}$ Determined at day 21 post-seeding of $1 \times 10^{3}$ cells ( $n=12 /$ treatment group). Results are presented as the mean \pm standard deviation. $\alpha=0.05<1 \mathrm{nM} \mathrm{E}_{2}$ vs. $20 \mathrm{nM} \mathrm{E}_{2}$. Data was analyzed by one-way analysis of variance and Dunnett's test $(\alpha=0.05)$. $\mathrm{E}_{2}, 17 \beta$-estradiol; AI, anchorage independent.

Table II. Inhibition of MCF-7 cell cycle progression by EG.

\begin{tabular}{|c|c|c|c|}
\hline \multirow[b]{2}{*}{ Treatment } & \multicolumn{3}{|c|}{ Cell cycle distribution ${ }^{\mathrm{a}}$} \\
\hline & $\% \mathrm{G}_{1}$ & $\% \mathrm{~S}+\mathrm{G}_{2} / \mathrm{M}$ & $\begin{array}{c}\mathrm{G}_{1}: \mathrm{S}_{+\mathrm{G}_{2} / \mathrm{M}} \\
\text { ratio }\end{array}$ \\
\hline Serum $0.7 \%\left(<1 \mathrm{nM} \mathrm{E}_{2}\right)$ & $82.3 \pm 8.2$ & $17.8 \pm 1.8$ & $4.6 \pm 0.5^{\mathrm{b}}$ \\
\hline $20 \mathrm{nM} \mathrm{E}_{2}$ & $67.3 \pm 6.7$ & $32.5 \pm 3.2$ & $2.1 \pm 0.2^{c}$ \\
\hline $20 \mathrm{nM} \mathrm{E}_{2}+1.0 \% \mathrm{EG}$ & $78.6 \pm 7.8$ & $21.4 \pm 3.8$ & $3.7 \pm 0.4^{\mathrm{d}}$ \\
\hline
\end{tabular}

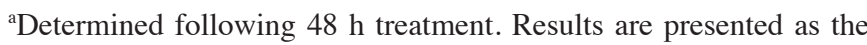
mean \pm standard deviation ( $\mathrm{n}=3 /$ treatment group). $\alpha=0.05^{\mathrm{b}}$ vs. ${ }^{\mathrm{c}}$; $\alpha=0.05^{\mathrm{b}}$ vs. ${ }^{\mathrm{d}} ; \alpha=0.05^{\mathrm{c}}$ vs. ${ }^{\mathrm{d}}$. Data was analyzed by one-way analysis of variance and Dunnett's test $(\alpha=0.05) . \mathrm{E}_{2}, 17 \beta$-estradiol; EG, Epimedium grandiflorum.

Table III. EG modulates the metabolism of $\mathrm{E}_{2}$ in MCF-7 cells.

\begin{tabular}{lcccc}
\hline & \multicolumn{4}{c}{$\mathrm{E}_{2}$ metabolite concentration ${ }^{\mathrm{a}}\left(\mathrm{ng} / 1.0 \times 10^{6}\right.$ cells $)$} \\
\cline { 2 - 5 } Treatment & $\mathrm{E}_{1}$ & $2-\mathrm{OHE}_{1}$ & $16 \alpha-\mathrm{OHE}_{1}$ & $\mathrm{E}_{3}$ \\
\hline $20 \mathrm{nM} \mathrm{E}_{2}$ & $2.7 \pm 0.1$ & $0.7 \pm 0.3$ & $1.8 \pm 0.8$ & $0.3 \pm 0.1$ \\
$20 \mathrm{nM} \mathrm{E}_{2}+$ & $11.7 \pm 0.6^{\mathrm{b}}$ & $4.2 \pm 0.3^{\mathrm{c}}$ & $2.2 \pm 0.5$ & $3.0 \pm 0.9^{\mathrm{d}}$ \\
$1.0 \% \mathrm{EG}$ & & & & \\
\end{tabular}

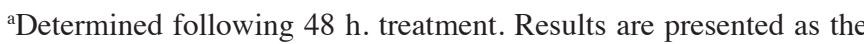
mean \pm standard deviation ( $\mathrm{n}=3 /$ treatment group). ${ }^{\mathrm{b}} \mathrm{P}=0.01,{ }^{\mathrm{c}} \mathrm{P}=0.006$, ${ }^{\mathrm{d}} \mathrm{P}=0.001$ compared with the $20 \mathrm{nM} \mathrm{E}_{2}$ control group. Data was analyzed using the Student's t-test. $\mathrm{E}_{2}, 17 \beta$-estradiol; $\mathrm{E}_{1}$, estrone; $\mathrm{OHE}_{1}$, hydroxyestrone; $\mathrm{E}_{3}$, estriol; EG, Epimedium grnadiflorum.

induced a 3.3-fold increase in $\mathrm{E}_{1}$ formation, a 5.0-fold increase in $2-\mathrm{OHE}_{1}$ formation and a 9.0 -fold increase in $E_{3}$ formation compared with the $E_{2}$ alone-treated control group. Additionally, the primary data were further analyzed and expressed as the $2-\mathrm{OHE}_{1}: 16 \alpha-\mathrm{OHE}_{1}$ and $\mathrm{E}_{3}: 16 \alpha-\mathrm{OHE}_{1}$ 


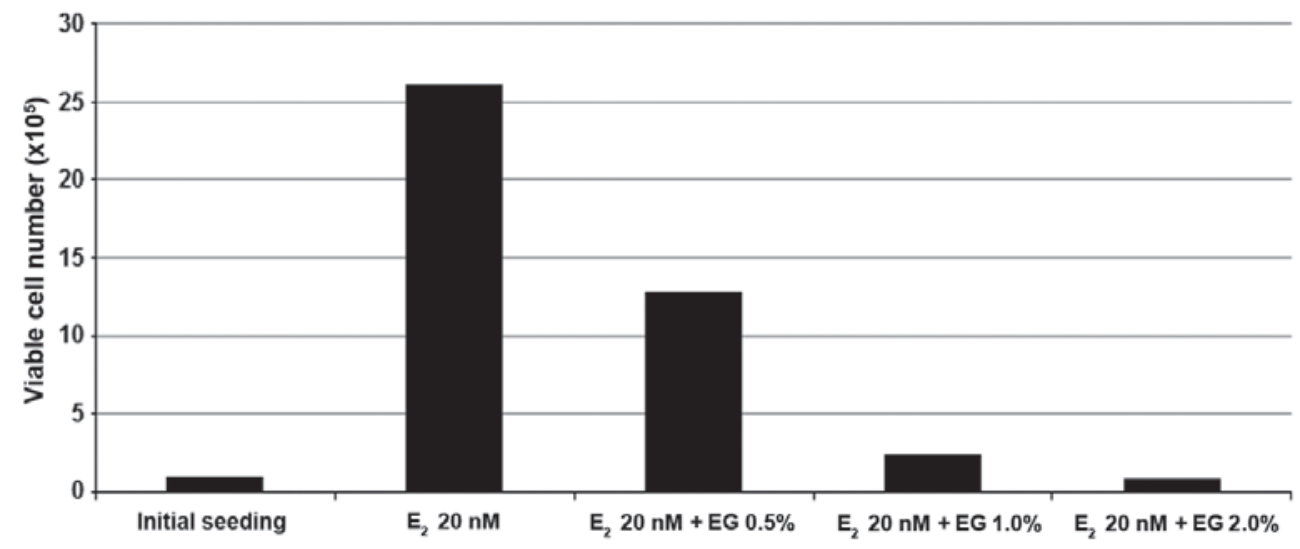

Figure 1. Dose-response analysis of EG in MCF-7 cells. The growth promoting effect of $\mathrm{E}_{2}$, represented by viable cell number, decreased in response to treatment with EG in a dose-dependent manner. EG IC $\mathrm{ID}_{50}, 0.49 \pm 0.18 \%$; $\mathrm{IC}_{90}, 1.03 \pm 0.17 \%$. Results are presented as the mean \pm standard deviation $(\mathrm{n}=6 /$ treatment group). $\mathrm{E}_{2} 20 \mathrm{nM}$ vs. $\mathrm{E}_{2} 20 \mathrm{nM}+\mathrm{EG} 0.5 \%\left(\mathrm{E}_{2}>\mathrm{E}_{2}+\mathrm{EG}, \alpha=0.05\right), \mathrm{E}_{2} 20 \mathrm{nM}$ vs. $\mathrm{E}_{2} 20 \mathrm{nM}+\mathrm{EG} 1.0 \%\left(\mathrm{E}_{2}>\mathrm{E}_{2}+\mathrm{EG}_{2}, \alpha=0.05\right)$, and $\mathrm{E}_{2} 20 \mathrm{nM}$ vs. $\mathrm{E}_{2} 20 \mathrm{nM}+\mathrm{EG}_{2.0 \%}$ $\left(\mathrm{E}_{2}>\mathrm{E}_{2}+\mathrm{EG}, \alpha=0.05\right)$. Data was analyzed using one-way analysis of variance and Dunnett's test $(\alpha=0.05)$. $\mathrm{E}_{2}, 17 \beta$-estradiol; EG, Epimedium grandiflorum.

ratios. This analysis revealed that the $2-\mathrm{OHE}_{1}: 16 \alpha-\mathrm{OHE}_{1}$ ratio was $0.39 \pm 0.16$ for the $\mathrm{E}_{2}$ alone-treated control group and $1.9 \pm 0.4$ for the $\mathrm{E}_{2}+\mathrm{EG}$-treated group, demonstrating a significant 3.9-fold increase $(\mathrm{P}=0.01)$ compared with the $\mathrm{E}_{2}$ alone-treated control group. Similarly, the $\mathrm{E}_{3}: 16 \alpha-\mathrm{OHE}_{1}$ ratio was $0.16 \pm 0.06$ for the $E_{2}$ alone-treated control and $0.58 \pm 0.14$ for the $\mathrm{E}_{2}+\mathrm{EG}$-treated group, demonstrating a significant 2.6-fold increase $(\mathrm{P}=0.03)$ compared with the $\mathrm{E}_{2}$ alone-treated control group.

Effect of EG on AI cell growth. Results from the investigation into the effect of EG on AI growth are presented in Fig. 2. The AI colony count in the serum-treated control group was $16.8 \pm 1.8$ compared with $36.9 \pm 2.1$ in the $\mathrm{E}_{2}$-treated group, illustrating a $119.6 \%$ increase compared with the control group $(\alpha=0.05)$. The AI colony count in the $0.5 \% \mathrm{EG}$ and $1.0 \%$ EG-treated groups was $18.1 \pm 1.0$ and $4.7 \pm 0.4$, respectively, compared with the $\mathrm{E}_{2}$ alone-treated control $(\alpha=0.05)$. Thus, treatment with $\mathrm{E}_{2}+0.5 \% \mathrm{EG}$ and $\mathrm{E}_{2}+1.0 \% \mathrm{EG}$ resulted in a substantial 50.9 and $87.3 \%$ decrease in the AI colony count, respectively, compared with the $\mathrm{E}_{2}$-treated control.

\section{Discussion}

The Luminal A molecular subtype of clinical breast cancer, defined by the expression of ER- $\alpha$ and PR, is typically treated with selective ER modulators and/or aromatase inhibitors, with or without cytotoxic drugs (3-6). These treatments are frequently associated with systemic toxicity and acquired tumor resistance, compromising therapeutic efficacy. Relatively non-toxic nutritional herbal products are used as therapeutic alternatives in traditional Chinese medicine. However, the long-term clinical safety, efficacy and potential interaction of nutritional herbs with traditional therapies remain unclear. The present study utilized the human mammary carcinoma-derived MCF-7 cell line (ER $\left.+\mathrm{PR}^{+} / \mathrm{HER}-2^{-}\right)$as a preclinical cell model of the Luminal A molecular subtype of breast cancer, in order to investigate the growth inhibitory effects of the nutritional herb EG and to identify possible molecular mechanisms for its efficacy.
MCF-7 cells that were maintained in a medium supplemented with $0.7 \%$ serum $\left(\mathrm{E}_{2},<1 \mathrm{nM}\right)$ retained their responsiveness to physiologically relevant concentrations of $E_{2}$. This response was demonstrated by an increase in the number of viable cells following treatment with $20 \mathrm{nM}$ of $\mathrm{E}_{2}$ compared with the serum-treated control group. In addition, at this physiological concentration $\mathrm{E}_{2}$ decreased cell population doubling time, increased saturation density and enhanced AI growth compared with the corresponding control groups. These data are consistent with a recent study, where $\mathrm{E}_{2}$ concentrations within the physiological range induced progressive increases in viable cell number (14). These results indicate that the method used in the current study produced an optimized $\mathrm{E}_{2}$-responsive cell culture model for the Luminal A molecular subtype of breast cancer.

Dose-response analysis demonstrated that $\mathrm{E}_{2}$-promoted cell growth was inhibited by EG in a dose-dependent manner, with an $\mathrm{IC}_{50}$ of $0.49 \%$ and $\mathrm{IC}_{90}$ of $1.03 \%$. EG at a concentration of $2.0 \%$ demonstrated a cytotoxic response, indicated by a significantly reduced viable cell count, relative to the initial seeding density. These data indicate that EG antagonizes the growth-promoting effect of $\mathrm{E}_{2}$.

The growth-promoting effect of $\mathrm{E}_{2}$ on MCF-7 cells was demonstrated when investigating the effect of $\mathrm{E}_{2}$ on cell cycle progression. These was a reduction in the $G_{1}: S+G_{2} / M$ ratio of cells in the $\mathrm{E}_{2}$-treated group compared with the serum-treated control group. Treatment of MCF-7 cells with $\mathrm{E}_{2}$ resulted in a decreased percentage of cells in the $\mathrm{G}_{1}$ phase, with a simultaneous increase in the percentage of cells in the $S$ phase of the cell cycle. At its $\mathrm{IC}_{90}$ concentration, EG inhibited the $\mathrm{E}_{2}$-induced cell cycle progression of MCF-7 cells, as demonstrated by a pronounced $\mathrm{G}_{1}$ stage arrest and simultaneous decrease in the number of cells in the $\mathrm{S}+\mathrm{G}_{2} / \mathrm{M}$ phases of the cell cycle. This alteration in cell cycle progression was associated with an increase in the $\mathrm{G}_{1}: \mathrm{S}+\mathrm{G}_{2} / \mathrm{M}$ ratio and suggests that the cytostatic effect of EG is predominantly due to the inhibition of $\mathrm{E}_{2}$-promoted cell cycle progression.

Data from the present study on the cytostatic effect of EG at a relatively low dose are consistent with previous studies investigating the effects of extracts from other nutritional 


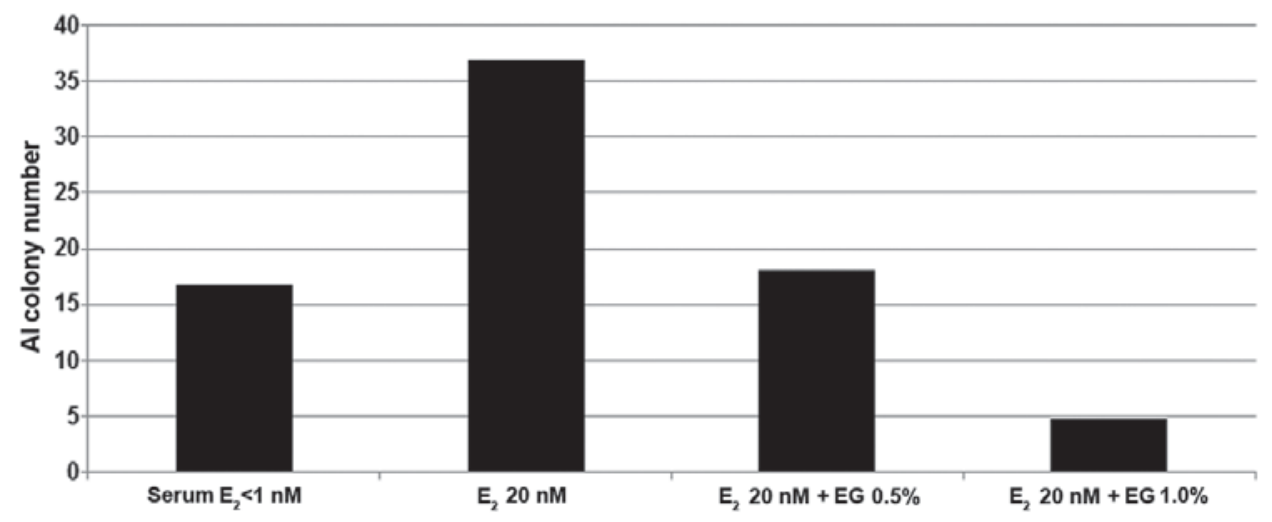

Figure 2. Effect of EG on the AI growth of MCF-7 cells. Results are presented as the mean \pm standard deviation (n=12/treatment group). $\mathrm{E}_{2}$ promoted AI growth of the cells, represented by the number of AI colonies, decreased in response to treatment with $\mathrm{EG}$ in a dose-dependent manner. Serum vs. $\mathrm{E}_{2} 20 \mathrm{nM}\left(\mathrm{serum}<\mathrm{E}_{2}\right.$ $\alpha=0.05), \mathrm{E}_{2} 20 \mathrm{nM}$ vs. $\mathrm{E}_{2} 20 \mathrm{nM}+\mathrm{EG} 0.5 \%\left(\mathrm{E}_{2}>\mathrm{E}_{2}+\mathrm{EG} \alpha=0.05\right), \mathrm{E}_{2} 20 \mathrm{nM}$ vs. $\mathrm{E}_{2} 20 \mathrm{nM}+\mathrm{EG} 1.0 \%\left(\mathrm{E}_{2}>\mathrm{E}_{2}+\mathrm{EG} \alpha=0.05\right)$. Data was analyzed using one-way analysis of variance and Dunnett's test $(\alpha=0.05)$. $\mathrm{E}_{2}, 17 \beta$-estradiol, EG, Epimedium grandiflorum; AI, anchorage independent.

herbs, such as Tabebuia avellandae (TA), $C O$ and $L B$, on MCF-7 cells $(9,10,13,14)$. The signaling pathways susceptible to extracts from TA, CO and LB include cell proliferation, cellular apoptosis, ER, xenobiotic metabolism and cell cycle progression through the modulated expression of specific genes $(9,10,13,14)$. Additionally, these extracts affect the cellular metabolism of $\mathrm{E}_{2}$, as demonstrated through the increased formation of specific anti-proliferative metabolites of $E_{2}(9-11,13,14)$. These results suggest that low-dose treatment with extracts from nutritional herbs is associated with an acceptable toxicity profile for future animal experiments and clinical trials.

The organ-selective growth-promoting effects of $E_{2}$ have been well established in cell culture and in vivo in animal models. Previously, $\mathrm{E}_{2}$ has been demonstrated to promote the growth of ER-positive MCF-7 cells in vitro, and promote tumor development in vivo (15). In addition to the effects of $\mathrm{E}_{2}$ on ER-dependent cellular signal transduction pathways $(5,6)$, specific cellular metabolites of $\mathrm{E}_{2}$ have been demonstrated to modulate the growth of mammary carcinoma-derived cells $(16,17)$. The intermediate metabolite $\mathrm{E}_{1}$ functions as a common precursor for the formation of the pro-mitogenic $16 \alpha-\mathrm{OHE}_{1}$ through the C16 $\alpha$-hydroxylation pathway, or for the formation of anti-proliferative $2-\mathrm{OHE}_{1}$ through the C2-hydroxylation pathway (16-21). The results of the present study demonstrated that treatment with EG significantly increased the formation of $\mathrm{E}_{1}, 2-\mathrm{OHE}_{1}$ and $\mathrm{E}_{3}$, while the formation of $16 \alpha-\mathrm{OHE}_{1}$ remained essentially unaltered, when compared with the $\mathrm{E}_{2}$-treated control group. Since the C2and $\mathrm{C} 16 \alpha$-hydroxylation pathways represent two divergent metabolic pathways generating distinct $\mathrm{E}_{2}$ metabolites, and since $E_{3}$ represents a proximate metabolite of $16 \alpha-\mathrm{OHE}_{1}$, the relative ratios of these metabolites serve as important endocrine biomarkers for carcinogenic risk $(9,10)$. In the present study, $\mathrm{E}_{2}$ metabolite ratios demonstrated that in response to the treatment with $\mathrm{EG}$, the $2-\mathrm{OHE}_{1}: 16 \alpha-\mathrm{OHE}_{1}$ and the $\mathrm{E}_{3}: 16 \alpha-\mathrm{OHE}_{1}$ ratios were substantially increased compared with the $\mathrm{E}_{2}$-treated control group. This indicates that $\mathrm{EG}$ selectively induces increased formation of 2- $\mathrm{OHE}_{1}$ and accelerates conversion of $16 \alpha-\mathrm{OHE}_{1}$ into $\mathrm{E}_{3}$. Notably, similar modulation of the cellular metabolism of $\mathrm{E}_{2}$ by extracts from $\mathrm{CO}$ and $\mathrm{LB}$ has been revealed $(9,10,14)$.

AI growth represents a specific and sensitive in vitro surrogate end-point biomarker for tumorigenic phenotypes $(9-11,14,20-22)$. In the current study, $\mathrm{E}_{2}$ promoted the formation of AI colonies by MCF-7 cells. In response to treatment with EG, the number of AI colonies decreased in a dose-dependent manner, supporting the potential of EG as an anti-tumorigenic agent.

The results of the present study provide mechanistic evidence for the growth inhibitory effect of EG in a cellular model of ER- $\alpha^{+} / \mathrm{PR}^{+} / \mathrm{HER}-2^{-}$Luminal A subtype breast cancer. A recent study compared the efficacy of several Chinese nutritional herbs on ER non-functional (ER-NF) and ER functional (ER-F) phenotypes of breast cancer (14), where EG demonstrated comparable growth inhibition in ER-NF and ER-F phenotypes, suggesting potential efficacy in ER- $\alpha^{-}$and ER- $\alpha^{+}$ breast cancer. In addition, an ongoing study into the growth inhibitory effects of EG in a ER- $\alpha / \mathrm{PR}^{-} / \mathrm{HER}-2$ - triple-negative MDA-MB-231 breast cancer cell model has elucidated the potential molecular mechanisms underlying the cell cycle arrest and induction of cellular apoptosis (Telang et al, unpublished results). These results suggest that EG is an anti-tumorigenic agent in ER- $\alpha$ and triple-negative breast cancer, in addition to the Luminal A subtype investigated in the present study.

It is well known that traditional herbal medicine combines the use of several herbal preparations and that these herbs contain several bioactive agents. Traditionally, herbs are boiled in water and consumed by patients as herbal tea (7,8,23-25). Therefore, to simulate patient consumption, non-fractionated aqueous extracts from EG were used as the test agent in the present study. Despite the growth inhibitory effects of the non-fractionated aqueous extract of EG demonstrated in the current study, the identity of the water-soluble bioactive agent(s) in this extract remain unclear. Methanolic extracts from EG containing icariin and icaritin have been demonstrated to effect multidrug resistance in HepG2/ADR cells (26). In contrast, the same methanol soluble bioactive agents induce growth promoting effects through the upregulation of epidermal growth factor receptor/mitogen-activated protein kinase 
signaling pathways in a model of HER-2 $2^{+}$breast cancer (27). Furthermore, organic solvent fractionated extracts from Epimedium brevicornum containing the prenylflavone breviflavone $\mathrm{B}$ have been demonstrated to exhibit inhibitory effects on ER- $\alpha$ expression, in addition to on the growth of ER- $\alpha^{+}$breast cancer cells in vitro and in vivo (28-30). The growth inhibitory effect of non-fractionated aqueous extract from EG in the present study and the growth modulatory effects of organic solvent fractionated extracts from different Epimedium species in previous studies, suggest that EG has a pleiotropic effect, which is likely due to the presence of distinct constitutive bioactive components. In addition to the MCF-7 cell line representing a model of the Luminal A subtype of breast cancer, MCF-7 cells have provided a model for endocrine therapy-resistant cancer stem cells (31). Investigations into the response of cancer stem cell models to EG may identify potential therapeutic targets for stem cell therapy. A study using a similar approach has identified the antitumorigenic efficacy of the phytochemicals quercetin and sulforaphane in pancreatic cancer stem cells (32).

In conclusion, the present study has identified distinct phenomenological and mechanistic evidence for the antitumorigenic efficacy of EG in the Luminal A molecular subtype of breast cancer. The results of the present study validate a mechanism-driven cell culture approach to prioritize efficacious herbal medicinal products for the treatment of patients with the $\mathrm{ER}^{+}$Luminal A molecular subtype of breast cancer.

\section{Acknowledgements}

The present study was supported by philanthropic contributions to the American Foundation for Chinese Medicine from the Sophie Stenbeck Family Foundation.

\section{References}

1. American Cancer Society: Cancer Facts \& Figures. American Cancer Society, Atlanta, CA, 2015.

2. Sørlie T, Perou CM, Tibshirany R, Aas T, Geisler S, Johnsen H, Hastie T, Eisen MB, van de Rijn M, Jeffrey SS, et al: Gene expression patterns of breast carcinomas distinguish tumor subclasses with clinical implications. Proc Natl Acad Sci USA 98: 10869-10874, 2001.

3. Dinh F, Satirou C and Piccart MJ: The evaluation of treatment strategies: Aiming at the target. Breast 16 (Suppl 2): S10-S16, 2007.

4. Lippman ME: Efforts to combine endocrine and chemotherapy in the management of breast cancer: Do two and two equals three? Breast Cancer res Treat 3: 117-127, 1983.

5. Johnston SR and Dowsett M: Aromatase inhibitors for breast cancer: Lessons from the laboratory. Nat Rev Cancer 3: 821-831, 2003.

6. Musgrove EA and Sutherland RL: Biological determinants of endocrine resistance in breast cancer. Nat Rev Cancer 9: 631-643, 2009.

7. Rock E and DeMichelle A: Nutritional approaches to late toxicities of adjuvant chemotherapy in breast cancer survivors. J Nutr 133 (11 Suppl 1): 3785S-3793S, 2003.

8. Hyler LK, Chin S, Chu BK, Fitzgerald B, Verma S, Rakovitch E, Dranitsaris $\mathrm{G}$ and Clemons $\mathrm{M}$ : The use of complementary and alternative medicine among patients with locally advanced breast cancer-a descriptive study. BMC Cancer 6: 39, 2006.

9. Telang NT, Li G, Sepkovic D, Bradlow HL and Wong GY: Anti-proliferative effects of Chinese herb Cornus officinals in a cell culture model for estrogen receptor-positive clinical breast cancer. Mol Med Rep 5: 22-28, 2012.

10. Telang NT, Li G, Sepkovic D, Bradlow HL and Wong GY: Comparative efficacy of Lycium barbarum bark and fruit on estrogen receptor positive human mammary carcinoma MCF-7 cells. Nutr Cancer 66: 278-284, 2014.
11. Suto A, Bradlow HL, Kubota T, Kitajima H, Wong GY, Osborne MP and Telang NT: Alteration in proliferative and endocrine responsiveness of human mammary carcinoma cells by prototype tumor-suppressing agents. Steroids 58: 212-219, 1993.

12. Katdare M, Osborne MP and Telang NT: Soy isoflavone genestein modulates cell cycle progression and induces apoptosis in HER-2/Neu oncogene expressing human breast epithelial cells. Int J Oncol 21: 809-815, 2002.

13. Mukherjee B, Telang N and Wong GY: Growth inhibition of estrogen receptor positive human breast cancer cells by Taheebo from the inner bark of Tabebuia avellandae tree. Int J Mol Med 24: 253-260, 2009

14. Telang N,Li G, Katdare M, Sepkovic D, Bradlow L and Wong GY: Inhibitory effects of Chinese nutritonal herbs in isogenic breast carcinoma cells with modulated estrogen receptor function. Oncol Lett 12: 3949-3957, 2016.

15. Lippman ME, Osborne CK, Knazek R and Young N: In vitro model systems for the study of hormone dependent human breast cancer. N Engl J Med 296: 154-159, 1977.

16. Yager D and Davidson NE: Estrogen carcinogenesis in breast cancer. N Engl J Med 354: 270-282, 2006.

17. Fishman J, Osborne MP and Telang NT: The role of estrogens in mammary carcinogenesis. NY Acad Sci 768: 91-100, 1995.

18. Schneider J, Huh MM, Bradlow HL and Fishman J: Anti-estrogen action of 2-hydroxyestrone on MCF-7 human breast carcinoma cells. J Biol Chem 259: 4840-4845, 1984.

19. Lottering ML, Haag M and Segers JC: Effects of 17beta-estradiol metabolites on cell cycle events in MCF-7 cells. Cancer Res 52: 5926-5932, 1992.

20. Telang NT, Suto A, Wong GY, Osborne MP and Bradlow HL: Induction by estrogen metabolite 16alpha-hydroxyestrone of genotoxic damage and aberrant proliferation in mouse mammary epithelial cells. J Natl Cancer Inst 84: 634-638, 1992.

21. Suto A, Telang NT, Tanino H, Takeshita T, Ohmiya H, Osborne MP and Kubota T: In vitro and in vivo modulation of growth regulation in human breast cancer cell line MCF-7 by estradiol metabolites. Breast Cancer 6: 87-92, 1999.

22. Telang $\mathrm{N}$ and Katdare $\mathrm{M}$ : Epithelial cell culture models for the prevention and therapy of clinical breast cancer (Review). Oncol Lett 3: 744-750, 2012.

23. Campbell MJ, Hamilton B, Shoemaker M, Tagliaferri M, Cohen I and Tripathi D: Antiproliferative activity of Chinese medicinal herbs on breast cancer cells in vitro. Anticancer Res 22: 3843-3852, 2002.

24. Chiu JH, Chang C, Wu JC, Liu HJ, Wen CS, Hsu CH, Chen JL, Tseng LM, Chen WS and Shyr YM: Screening to identify commonly used Chinese herbs that affect ERB2 and ESR-1 gene expression using the human breast cancer MCF-7 cell line. Evid Based Complement Alternat Med 2014: 965486, 2014.

25. Ye L, Jia Y, Ji KE, Sanders AJ, Xue K, Ji J, Mason MD and Jiang WG: Traditional Chinese medicine in the prevention and treatment of breast cancer and cancer metastasis. Oncol Lett 10: 1240-1250, 2015

26. Sun L, Chen W, Qu L, Wu J and Si J: Icaritin reverses multi-drug resistance of HepG2/ADR human hepatoma cells via downregulation of MDR1 and P-glycoprotein expression. Mol Med Rep 8: 1883-1887, 2013.

27. Ma HR, Wang J, Chen YF, Chen H, Wang WS and Aisa HA: Icariin and Icaritin stimulate the proliferation of SKBr-3 cells through the GPER1-mediated modulation of the EGFR-MAPK signaling pathway. Int J Mol Med 33: 1627-1634, 2014.

28. Yap SP, Shen P, Butler MS, Gong Y, Loy CJ and Yong EL: New estrogenic prenylflavone from Epimedium brevicornum inhibits the growth of breast cancer cells. Planta Med 71: 114-119, 2005.

29. Yap SP, Shen PJ, Li J, Lee LS and Yong EL: Molecular and pharmaco-dynamic properties of estrogenic extracts from the traditional Chinese medicinal herb, Epimedium. J Ethno-pharmacol 113: 218-224, 2007.

30. Indran IR, Zhang SJ, Sun F, Gong Y, Wang X, Wang X, Li J, Erdelmeier CA, Koch E and Yong EL: Selective estrogen receptor modulator effects of epimedium extracts on breast cancer and uterine growth in nude mice. Planta Med 80: 22-28, 2014

31. Telang N: Putative cancer-initiating stem cells in cell culture models for molecular subtypes of clinical breast cancer. Oncol Lett 10: 3840-3846, 2015.

32. Zhou W, Kallifatidis G, Baumann B, Rausch V, Mattern J, Gladkich J, Giese N, Moldenhauer G, Wirth T, Büchler MW, et al: Dietary polyphenol quercetin targets pancreatic cancer stem cells. Int J Oncol 37: 551-561, 2010. 